\title{
Serum Insulin-Like Growth Factor-II (IGF-II) Levels in Patients with Acromegaly and Growth Hormone Deficiency: Correlation with IGF-I and IGF Binding Protein-3
}

\author{
AKIRA SHIMATSU, Yoshio NAKAMURA*, CHIHIRO IHARA*, \\ Haruo MIZUTA*, AND HiroyUKI MURABE* \\ Department of Laboratory Medicine, and $*$ Department of Medicine and Clinical Science, \\ Kyoto University Graduate School of Medicine, Kyoto 606-01, Japan
}

INSULIN-LIKE growth factor-I (IGF-I) and IGF-II are bound to the specific IGF-binding proteins (IGFBPs) in the circulation. Among the six IGFBPs so far characterized, IGFBP-3 is the most abundant. The measurement of IGF-I and IGFBP-3 levels is useful for the diagnosis of $\mathrm{GH}$ disorders, since both parameters are $\mathrm{GH}$ dependent, but the significance of IGF-II, which is less dependent on GH, remains to be determined. In the present study, we measured serum levels of IGF-II together with IGF-I and IGFBP-3 in normal subjects, acromegalic patients and GH deficiency in adults, and investigated the interrelationship among these parameters.

\section{Subjects and Methods}

Fifty normal subjects aged from 21 to 89 years, 32 patients with acromegaly (age: $24-64 \mathrm{yr}$ ) and 21 patients with GH deficiency (age: 22-68 yr) were included in the study. The acromegalic patients were subdivided into two groups, active and inactive, according to the clinical activities such as acral enlargement, excessive sweating, headache and arthralgia. GH deficiency was diagnosed by the inadequate $\mathrm{GH}$ responses to insulin-induced hypoglycemia (peak GH levels less than $3 \mathrm{ng} / \mathrm{ml}$ ). All patients with GH deficiency were associated

Correspondence to: Dr. Akira SHIMATSU, Department of Laboratory Medicine, Kyoto University Graduate School of Medicine, 54 Shogoin Kawahara-cho, Sakyo-ku, Kyoto 60601, Japan.

Key words: Insulin-like growth factor-II (GF-II), IGF-I, IGF binding protein-3 (IGFBP-3), Immunoradiometric assay, Acromegaly, GH deficiency in adults with other pituitary hormone deficiencies and received adequate replacement therapy except GH.

Serum levels of IGF-II, IGF-I and IGFBP-3 were determined by specific immunoradiometric assays (IRMAs), as described previously [1]. Since IGFs were log-normally distributed, data were log-transformed to calculate the reference ranges (mean \pm 2SD).

\section{Results}

In normal subjects, serum IGF-II levels were stable throughout adulthood, whereas serum levels of IGF-I and IGFBP-3 were decreased with age. In patients with active acromegaly, serum levels of IGF-I and IGFBP-3 were noticeably increased but IGF-II levels were within the reference range, as shown in Fig. 1. After successful therapy, IGF-I decreased to normal or low-normal levels and IGFII remained normal. Almost all patients with GH deficiency had low levels of IGF-I. Serum levels of IGF-II and IGFBP-3 were lower than in normal subjects, but one-third of patients with GH deficiency had normal IGF-II and IGFBP-3.

There was a weak positive correlation between IGF-II and IGF-I levels in normal subjects and GH deficient patients. IGFBP-3 levels were best correlated with $\log$ IGF-I $(\mathrm{r}=0.75)$. IGF-II levels were correlated with IGFBP-3 in all subjects except active acromegaly ( $r=0.86)$. As shown in Fig. 2, the sum of IGF-II and IGF-I showed a strong positive correlation with IGFBP-3 levels $(\mathrm{r}=0.88)$. The calculated ratio of IGF-I to IGFBP-3 was not superior to IGF-I or IGFBP-3 alone to distinguish acrome- 

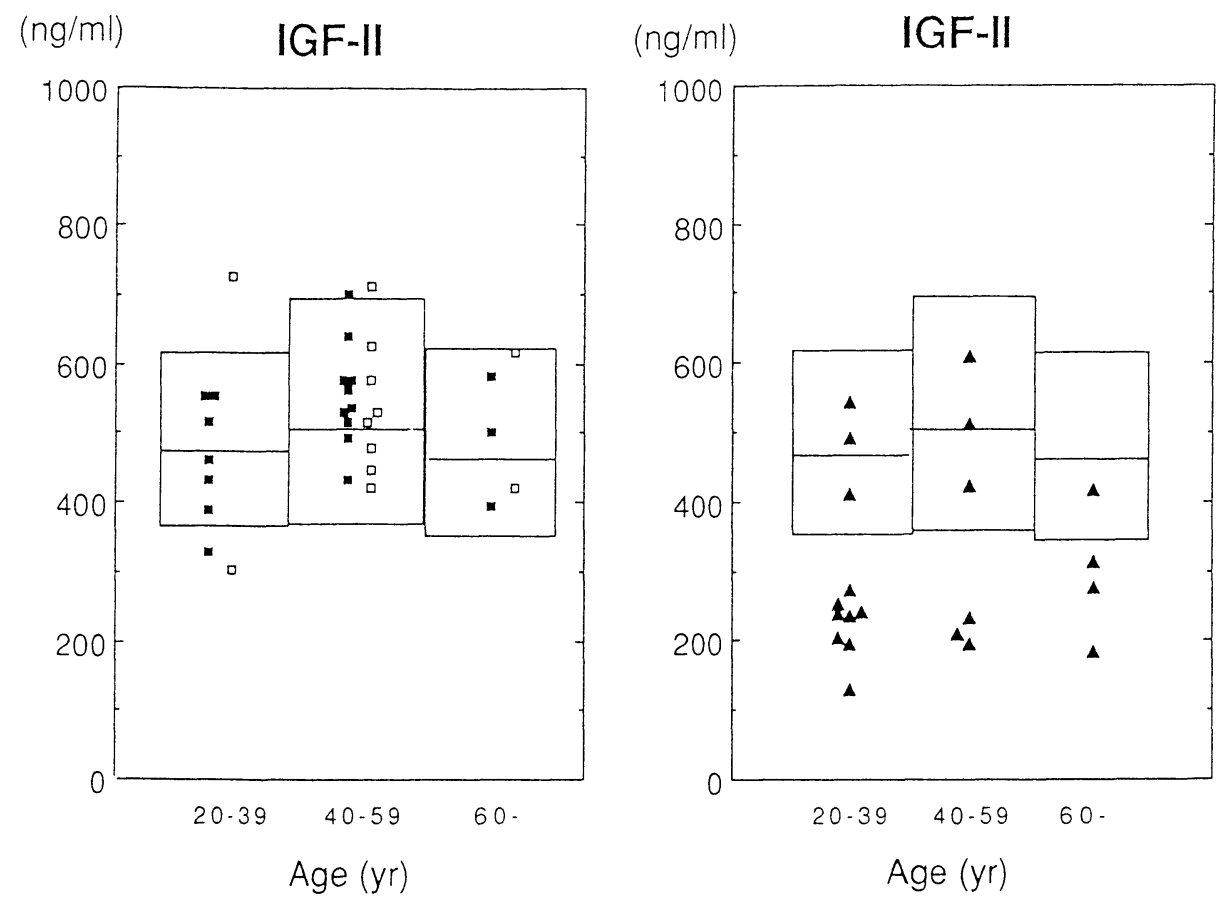

Fig. 1. Serum IGF- II levels in patients with active ( $\square$ ) and inactive ( $\square$ ) acromegaly and GH deficiency in adults ( $\boldsymbol{A})$. Bars and boxes indicate the mean $\pm 2 \mathrm{SD}$ of normal subjects.

\section{IGFBP-3 (ng/ml)}

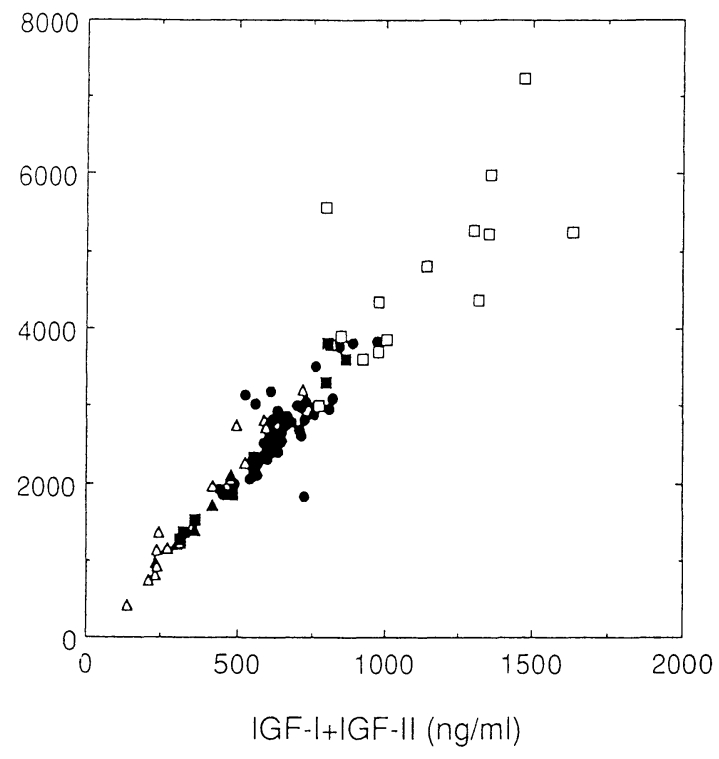

Fig. 2. Correlation between IGFBP-3 and the sum of IGF-I and IGF-II in normal subjects (O), patients with acromegaly $(\square)$, and GH deficiency in adults $(\triangle)$. galy or GH deficiency from normal subjects in the present study.

\section{Discussion}

In the present study, IGF-II concentrations were measured by a newly developed IRMA using a non-extraction method. The serum levels were lognormally distributed, and the mean IGF-II values in normal adults were around $500 \mathrm{ng} / \mathrm{ml}$, which were somewhat less than the values in radioimmunoassays (RIAs) previously reported [2-7]. The discrepancy may be partly caused by the different cross-reactivities of IGF related peptides and degraded fragments of IGF-II in various assays using different antibodies or by different IRMA and RIA methods.

Serum IGF-II levels were stable throughout adulthood, in contrast to the levels of IGF-I and IGFBP-3. Daughaday et al. [3] reported that serum IGF-II determined by radioreceptor assay was greater in adults more than 70 years of age, but we did not observe this phenomenon in our normal 
subjects. Serum IGF-II levels were within the reference range in active and inactive acromegaly in accordance with others $[2-4,8]$ except one report [9]. We found that serum IGF-II levels were lower in patients with GH deficiency than in normal subjects, but considerable overlaps were observed. Other investigators $[2,4,5]$ have reported better discrimination of $\mathrm{GH}$ deficiency from normal subjects, but Rosenfeld [6] and Asakawa [9] have reported similar findings to in ours in pediatric patients. Serum IGF-II levels were therefore only partially dependent on $\mathrm{GH}$, and other factors which regulate IGF-II levels remain to be determined.

The sum of serum IGF-I and IGF-II levels correlated significantly with serum IGFBP-3 in all subjects. This has previously been demonstrated in healthy individuals [10]. The ratio of IGF-I to IGFBP-3 has been reported to reflect free IGF-I [11], but we observed marked overlaps between acromegaly and normal subjects and the ratio of IGF-I to IGFBP-3 levels was not superior to IGF-I or IGFBP-3 alone in the present study. Serum IGF-II levels were correlated with IGFBP-3 in normal subjects and GH deficiency in adults. Simultaneous measurement of IGF-I, IGF-II and IGFBP-3 may provide further insights in understanding the pathophysiology of GH disorders.

\section{Acknowledgements}

We thank Daiichi Radioisotope Research Laboratories for kindly measuring IGFs and IGFBP-3 levels. This work was in part supported by a Grantin-Aid from the Ministry of Health and Welfare, Japan.

\section{References}

1. Shimatsu A, Fujieda K (1996) Simultaneous measurement of IGF-I, IGF-II and IGFBP-3 levels in patients with growth hormone disorders. Horumon to Rinsho 44: 393-400 (In Japanese).

2. Zapf J, Walter H, Froesch ER (1981) Radioimmunological determination of insulin-like growth factors I and II in normal subjects and in patients with growth disorders and extrapancreatic tumor hypoglycemia. J Clin Invest 68: 1321-1330.

3. Daughaday WH, Trivedi B, Kapadia M (1981) Measurement of insulin-like growth factor II by a specific radioreceptor assay in serum of normal individuals, patients with abnormal growth hormone secretion, and patients with tumor-associated hypoglycemia. J Clin Endocrinol Metab 53: 289-294.

4. Hintz RL, Liu F (1982) A radioimmunoassay for insulin-like growth factor II specific for the C-peptide region. J Clin Endocrinol Metab 54: 442-446.

5. Enberg G, Hall K (1984) Immunoreactive IGF-II in serum of healthy subjects and patients with growth hormone disturbances and uraemia. Acta Endocrinol 107: 164-170.

6. Rosenfeld RG, Wilson DM, Lee PDK, Hintz RL (1986) Insulin-like growth factors I and II in evalu- ation of growth retardation. J Pediatr 109: 428-433.

7. Blum WF, Ranke MB, Bierich JR (1988) A specific radioimmunoassay for insulin-like growth factor II: The interference of IGF binding proteins can be blocked by excess IGF- I. Acta Endocrinol 118: 374 380 .

8. Jørgensen JOL, Møller N, Møller J, Weeke J, Blum WF (1994) Insulin-like growth factors (IGF)-I and II and IGF binding protein-1, -2 , and -3 in patients with acromegaly before and after adenomectomy. Metabolism 43: 579-583.

9. Asakawa K, Hizuka N, Takano K, Fukuda I, Sukegawa I, Demura H, Shizume K (1990) Radioimmunoassay for insulin-like growth factor II (IGFII). Endocrinol Japon 37: 607-614.

10. Baxter RC (1988) The insulin-like growth factors and their binding proteins. Comp Biochem Physiol 91B: 229-235.

11. Juul A, Main K, Blum WF, Lindholm J, Ranke MB, Skakkebaek NE (1994) The ratio between serum levels of insulin-like growth factor (IGF)-I and the IGF binding proteins (IGFBP-1,2 and 3) decreases with age in healthy adults and is increased in acromegalic patients. Clinical Endocrinology 41: 85-93. 